\title{
Posttraumatic Septic Arthritis Due to Serratia marcescens: Case Report and Review of Literature
}

\author{
Serratia marcescens'e Bağlı Posttravmatik Olarak Gelișen Septik Artrit: Olgu Sunumu ve \\ Literatürün Gözden Geçirilmesi
}

\author{
Ali Ilgın OLUT'1, Selma TOSUN' ${ }^{1}$, Alpay ARI', Burak ŞEKER', Halil ERKAN', Taşkın ALTAY² \\ ${ }^{1}$ Izmir Bozyaka Training and Research Hospital, Clinic of Infectious Diseases and Clinical Microbiology, Izmir, Turkey \\ ${ }^{2}$ Izmir Bozyaka Training and Research Hospital, Clinic of Orthopaedics and Traumatology, Izmir, Turkey
}

\section{Abstract}

Septic arthritis is classified among the acute emergencies of joint diseases. Gram-positive cocci are responsible in 75-80\% of the cases, while Gramnegative bacilli may be the etiological agents in case of compromised immunity, intravenous drug abuse, advanced age, or iatrogenic infections. Cases of posttraumatic septic arthritis due to Gram-negative bacilli in immunocompetent patients are reported in the literature. In this paper we present a severe septic arthritis due to Serratia marcescens in a 43-year-old man with multiple trauma, right patellar and femoral condyle fracture after a traffic accident, three days after an irrigation and debridement procedure was performed. The surgical procedure had to be repeated four times while he was receiving medical treatment. A literature search in PubMed using the keywords "Serratia marcescens and septic arthritis" on 0ctober $10^{\text {th }} 2017$, we found 37 articles, of which 18 were case reports or case series. Of those 18 articles, seven cases were hospital-acquired, five were in intravenous drug users, two were trauma related, one was concomitant with rheumatoid arthritis, one was in a neonate, one was due to intra-articular injection, and one article described an epidemic due to usage of contaminated benzalkonium chloride solution as an antiseptic. We also found a case by searching Turkish Medline reported in a ten-week-old baby with Escobar syndrome. In our case, although hospital-acquired infection cannot be ruled out, we believe that this was a community-acquired infection due to contamination of the open dirty wound, as the irrigation procedure was done in sterile operating room conditions and no other such case has ever been identified. As prompt diagnosis and treatment is critical in prognosis of septic arthritis, we emphasize the possible role of Gram-negative bacilli in posttraumatic cases.

Keywords: Septic arthritis, Serratia marcescens, posttraumatic, generic antibiotics, ertapenem

Septik artrit, eklemle ilgili acil hastalıklar arasında sınıflandırılır. Erken tanı ve tedavi prognoz açısından oldukça önem taşır. Tüm olgularda en sık görülen etkenler \%75-80 oranında Gram-olumlu koklardır. Ancak immün yetmezlik, damar içi ilaç alışkanlığı, ileri yaşlar veya iyatrojenik olgularda Gram-olumsuz basiller de etken olabilirler. Literatürde immünkompetan hastalarda da travma sonrası gelişen Gram-olumsuz basillere bağlı artritler bildirilmektedir. Bu yazıda trafik kazası sonucu multitravma, sağ patella ve sağ femoral kondil kırığı ile başvuran 43 yaşındaki erkek olguda debridman ve yıkama işlemi sonrasında üçüncü gün gelişen, Serratia marcescens'e bağlı şiddetli septik artrit olgusu sunulmuştur. Antibiyoterapi alırken cerrahi yıkama işleminin biri açık artrotomi olmak üzere dört kez tekrarlanması gerekmiştir. PubMed'de 10 Ekim 2017'de anahtar kelime olarak "Serratia marcescens ve septic arthritis" kullanılarak yapılan taramada 37 adet makale bulunmuş ve olgu bildiren 18 makale incelenmiştir. Makalelerin yedisi hastane kaynaklı, beşi damar içi ilaç alışkanlığı, ikisi travmaya bağlı, biri romatoid artrit zemininde gelişen, biri yenidoğanda, biri intraartiküler steroid enjeksiyonu sonrasında, biri kontamine benzalkonium klorid ile antisepsiye bağlı epidemi olmak üzere olgu veya olgu serileri olarak bildirilmiştir. Ayrıca Türk Atıf Dizini'nde on haftalık "Escobar" sendromlu bir bebekte rapor edilmiştir. Olgumuzda ilk debridman/yıkama işlemi sırasında eklem sıvısı örneği alınmadığından hastane kökenli septik artrit dışlanamamakla birlikte operasyonun steril ameliyathane şartlarında yapılması ve sürekli uygulanan bu prosedür sonrasında benzer bir duruma rastlanmamış olması nedeniyle olgunun açık-kirli yara sonrası kontaminasyona bağlı toplum kaynaklı septik artrit olduğu düşünülmüştür. Septik artritin erken tanı ve tedavisinin prognoz açısından önem taşıması nedeniyle posttravmatik septik artritlerde ampirik tedavi başlarken etken olarak Gram-olumsuz basillerin göz önüne alınması gerekliliği vurgulanmıştır.

Anahtar Kelimeler: Septik artrit, Serratia marcescens, posttravmatik, jenerik antibiyotikler, ertapenem

Cite this article as: Olut Al, Tosun S, Arı A, Şeker B, Erkan H, Altay T. Posttraumatic Septic Arthritis Due to Serratia marcescens: Case Report and Review of Literature. Mediterr J Infect Microb Antimicrob. 2017;6:13.

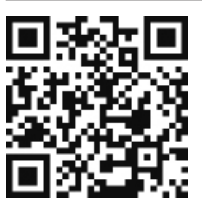

Address for Correspondence/Yazışma Adresi: Ali llgın Olut MD, İzmir Bozyaka Trainig and Research Hospital,

Clinic of Infectious Diseases and Clinical Microbiology, Izmir, Turkey

Phone: +90 5322643472 E-mail: iolut@yahoo.com ORCID ID: orcid.org/0000-0003-4129-6453

Received/Geliş Tarihi: 18.08.2017 Accepted/Kabul Tarihi: 15.11.2017

๑Copyright 2017 by the Infectious Diseases and Clinical Microbiology Specialty Society of Turkey

Mediterranean Journal of Infection, Microbes and Antimicrobials published by Galenos Yayinevi.

Published: 1 December 2017 


\section{Introduction}

Septic arthritis is inflammation of the synovial membrane and synovial fluid (SF) of the joints caused by bacterial, viral, or fungal agents. The synovial membrane is a highly vascular structure; however, it is to prone to infections due to the lack of a basement membrane ${ }^{[1]}$. Risk factors include the presence of rheumatoid arthritis, diabetes, hypogammaglobulinemia, chronic liver/kidney disease, cancer, alcoholism, and advanced age, as well as undergoing joint aspiration or surgery and receiving immunosuppressive therapy ${ }^{[2,3]}$. The knee joint is reported in nearly all studies as the most commonly affected joint, accounting for $45 \%$ of the cases on average ${ }^{[4]}$. Septic arthritis is classified as an emergent articular disease and early diagnosis and treatment are of great importance in terms of prognosis. With early treatment, approximately $80 \%$ of patients recover with no sequelae, whereas this is $30 \%$ less likely in those treated seven days later ${ }^{[5]}$. The definitive diagnosis is established by macroscopic, microscopic, microbiological, and biochemical evaluation of SF aspirated in sterile conditions. Leukocyte count over 50,000/ $\mathrm{mm}^{3}$ and polymorphonuclear leukocyte (PNL) ratio over $80 \%$ in SF are findings in favor of acute bacterial infection ${ }^{[6]}$. Gram-positive bacteria are seen at rates of $75-$ $80 \%$, Gram-negative bacteria at $40-50 \%$, and gonococci at 20$25 \%$ in Gram staining. SF cultures are positive in about $60 \%$ of cases on average, and diagnosis is established with SF and blood culture in another $14 \%$, demonstrating the importance of obtaining blood culture in addition to $\mathrm{SF}^{[7]}$. Immediately following diagnosis, purulent fluid in the joint should be drained and the infection should be treated with appropriate antibiotics. The infectious agent varies according to the pathogenesis of the infection and host risk factors. The most common etiologic agents are Gram-positive cocci in 75-80\% and Gram-negative bacilli in 10-15\% of cases ${ }^{[8,9]}$. In particular, Staphylococcus aureus is the most common cause of septic arthritis because it contains surface adhesion molecules linked to extracellular matrix proteins ${ }^{[10]}$. However, Gram-negative bacilli may be the infectious agent in immunocompromised patients, intravenous drug addicts, and elderly or iatrogenic cases ${ }^{[8,9]}$. These cases develop more extensive joint destruction, higher incidence of sequelae, and longer treatment duration ${ }^{[11]}$. In this case report and review, we present a case of septic arthritis due to Serratia marcescens in an immunocompetent patient and emphasize that Gram-negative bacilli should be considered as the etiologic factor in posttraumatic septic arthritis.

\section{Case Report}

A 43-year-old male patient presented to the Orthopedic Clinic after an intravehicular traffic accident with multitrauma and fractures of the right patella and right femoral condyle. In sterile operating conditions, the joint was irrigated with 2 liters of saline with rifampin + cefazolin, after which the wound was debrided and sutured. Because it was an open, dirty wound, prophylactic cefazolin and gentamicin therapy was initiated. On the third postoperative day, the patient developed fever, nausea, vomiting, and severe knee pain and the irrigation/ debridement procedure was repeated. SF examinations revealed $70,000 / \mathrm{mm}^{3}$ leukocyte count, $80 \% \mathrm{PNL}$, and Gram-negative bacilli. The antibiotic treatment was switched from cefazolin/ gentamicin to piperacillin-tazobactam therapy. Tests conducted at this time were as follows: erythrocyte sedimentation rate 94 $\mathrm{mm} / \mathrm{h}, \mathrm{C}$-reactive protein (CRP) was $92 \mathrm{pg} / \mathrm{mL}$, leukocyte count $22,000 / \mathrm{mm}^{3}$ (87\% PNL), liver and renal function tests normal, fasting blood glucose $105 \mathrm{mg} / \mathrm{dL}$ and hepatitis serologic markers and anti-HIV tests were negative. S. marcescens was isolated in the patient's SF culture (automated systems BD Phoenix ${ }^{\text {TM }}$ Automated Microbiology System, BD Diagnostics, France). Antibiotic susceptibility test was performed by disc diffusion method according to recommendations of the "Clinical and Laboratory Standards Institute"[12]. The isolate was resistant to ampicillin, gentamicin, cefazolin, cefuroxime, and amoxicillinclavulanate, and susceptible to ciprofloxacin, ceftriaxone, trimethoprim-sulfamethoxazole, ertapenem, and piperacillintazobactam. The patient's symptoms did not improve and elevated erythrocyte sedimentation rate and CRP levels persisted despite one week of piperacillin-tazobactam therapy, leading us to believe we had been unable to achieve adequate debridement; therefore, we repeated debridement and irrigation again via open arthrotomy. In addition, considering possible low generic efficacy, piperacillin-tazobactam was discontinued and ertapenem treatment was started. Culture obtained during that process was again positive for $S$. marcescens. The surgical cleaning procedure was repeated twice during the four weeks of ertapenem therapy. SF cultures taken during these procedures were negative. After the patient was discharged, he was referred to the physiotherapy unit for joint rehabilitation due to limited movement in his right knee. At six-month follow-up, we learned that he had $30 \%$ restriction of motion in the joint despite treatment.

\section{Literature Review}

Septic arthritis due to Serratia, a Gram-negative bacteria, is rarely encountered. A PubMed search conducted on October $10^{\text {th }}, 2017$ using the keywords "Serratia marcescens" and "septic arthritis" yielded 37 articles; as a result of the literature review, 14 papers in English or Turkish involving cases of septic arthritis due to $S$. marcescens which were not part of reviews, veterinary literature, or other repeated cases (e.g. as part of drug addiction case series) were analyzed, and they are presented with possible sources of infection, treatment, and outcomes in Table $1^{[13,16-}$ 
21,23-29]. In addition, one case was found in the Turkish Medical Directory using the key words "Serratia" and "septik artrit". Primary S. marcescens septic arthritis was first reported by Atlas and Belding ${ }^{[13]}$ in 1968 in JAMA in a 62-year-old woman with severe diabetes and urinary tract infection due to $S$. marcescens. The authors pointed out the rapid and destructive progression to amputation despite the treatment with kanamycin, to which the infecting strain was susceptible ${ }^{[13]}$. In the literature, this agent is usually reported in patients with nosocomial infection or severe immunosuppression ${ }^{[13-16]}$. Epidemic $S$. marcescens arthritis was first reported by Nakashima et al. ${ }^{[17]}$ as an iatrogenic infection in ten patients using contaminated benzalkonium chloride antiseptic agent. Ross et al. ${ }^{[18]}$ isolated S. marcescens in four intravenous heroin addicts in 1975, thus highlighting the relative prevalence of the pathogen among drug addicts for the first time. An immunocompetent case with no history of hospital admission or drug addiction was first reported by Lafuente Martinez et al. ${ }^{[19]}$ in 1981 in a 17-yearold patient, and the authors noted that the agent had been increasingly isolated in recent years. Hadid et al. ${ }^{[20]}$ reported septic arthritis in the ankle in an article entitled "Severe Osteomyelitis and Septic Arthritis due to Serratia marcescens in an Immunocompetent Patient" and emphasized that the etiology was rare. However, they stated that the patient was 72 years old and had uncontrolled diabetes, and that because he played golf, he may have acquired the agent from the soil after a minor trauma. There are also reports in the literature of arthritis due to Gram-negative bacteria and polymicrobial factors after trauma. Chiu and Wang ${ }^{[21]}$ isolated S. marcescens in knee arthritis in an immunocompetent patient following a motorcycle accident. As in our case, that patient was initially treated empirically for Gram-positive agents, then switched to ciprofloxacin based on the culture results, and arthrotomy/ arthroscopy and debridement were done four times before negative culture was obtained. The patient had severe limitation of motion in the joint after treatment and was referred to an intensive physiotherapy program. The authors emphasized the difficulty of eradicating the agent in Gram-negative arthritis, and the importance of surgical debridement, early selection of appropriate antibiotics, and intensive physiotherapy. This year, for the first time in Turkey, Sandal et al. ${ }^{[22]}$ from İzmir Dr. Behçet Uz Children's Hospital reported septic arthritis of the knee due to S. marcescens in a ten-week-old baby with Escobar syndrome. The patient had no permanent deformity after six weeks of meropenem treatment, which the authors attributed to early diagnosis, urgent aspiration, appropriate empirical treatment, and the initiation of joint opening exercises and muscle stretching exercises to prevent deformity.

\section{Discussion}

Immediate surgical drainage as well as early initiation of appropriate antibiotics are important for prognosis in the treatment of septic arthritis. If Gram-positive cocci are observed in Gram staining of SF samples, vancomycin is recommended until it is proven in culture antibiogram that the agent is not resistant to methicillin; if Gram-negative bacilli are observed, it is recommended to start treatment with ceftazidime, cefepime, piperacillin-tazobactam, or carbapenem. In cases where the agent could not be detected, the route of infection (hematogenous, direct inoculation, etc.), the patient's immune status, and age should be considered when selecting an empirical antibiotic. In general, the recommended vancomycin should be started in combination with ceftazidime or an antibiotic from the quinolone group (ciprofloxacin, levofloxacin). In patients with vancomycin allergy or intolerance, daptomycin or linezolid are alternative options ${ }^{[30]}$.

It is known that septic arthritis caused by Gram-negative bacteria has a poorer prognosis. It has been reported that longer treatment duration is necessary because treatment response is lower and complications such as ankylosis, secondary osteomyelitis, flexion contracture, chronic effusion, and recurrent infections are more common ${ }^{[10,11]}$. Septic arthritis due to Gram-negative bacilli in immunocompetent patients is rare, and has been reported in the literature as case reports or case series ${ }^{[10,11,14-17]}$. Lin et al. ${ }^{[14]}$ reported in a series of 194 septic arthritis cases of which $48(24.7 \%)$ were due to Gramnegative bacteria. In the same series, $56.3 \%$ of the patients had at least one underlying immunosuppressive condition, 29.2\% had gut disease, and $62.5 \%$ were over 65 years of age. The authors emphasized that broad-spectrum antibiotherapy that cover Gram-negative bacteria should be considered, especially in immunosuppressed and/or older patients.

In our case, S. marcescens was identified as the etiologic agent of septic arthritis in an immunocompetent patient who presented with open/dirty wound after trauma. Like other members of the Enterobacteriaceae family, S. marcescens is naturally resistant to penicillin G, macrolides, clindamycin, linezolid, glycopeptides, and quinupristin/dalfopristin. Serratia spp. are also generally resistant to ampicillin, amoxicillin, amoxicillin-clavulanate, ampicillin-sulbactam, first generation cephalosporins, cefuroxime, nitrofurantoin, colistin, and tetracyclines ${ }^{[29,31]}$. Therefore, it is recommended to start treatment for Serratia infections with piperacillin-tazobactam, fluoroquinolone, or carbapenem and to adjust treatment if necessary according to antibiotic susceptibility pattern ${ }^{[16]}$.

Although no SF sample was taken during the first debridement/ washing procedure and the case was consistent with definitions 
Table 1. Serratia marcescens-associated septic arthritis cases, possible sources of infection, treatment, and outcomes

\begin{tabular}{|c|c|c|c|c|c|}
\hline Researcher/year & Case & Affected joint & Possible source & Treatment & Outcome \\
\hline Atlas and Belding ${ }^{[13]}$ & $62, M$ & Knee & Urinary tract infection & Kanamycin & Amputation \\
\hline Burton and Nage ${ }^{[23]}$ & $50, F$ & Hip & $\begin{array}{l}\text { Rheumatoid arthritis and urinary } \\
\text { tract infection }\end{array}$ & Chloramphenicol & Joint dislocation \\
\hline Rogala and Cruess ${ }^{[24]}$ & $37, F$ & Hip, knee & Renal transplantation & Gentamicin & Avascular necrosis \\
\hline Ross et al. ${ }^{[18]}$ & 5 cases & Knee, sacroiliac & Intravenous drug use & Various & $\begin{array}{l}4 \text { recovered, } 1 \\
\text { permanent joint } \\
\text { contracture }\end{array}$ \\
\hline Donowan et al. ${ }^{[16]}$ & 7 cases & Knee, hip, ankle & $\begin{array}{l}\text { Intravenous drug use, } \\
\text { Immunosuppression }\end{array}$ & Various & $\begin{array}{l}3 \text { recovered } \\
4 \text { permanent } \\
\text { sequelae }\end{array}$ \\
\hline $\begin{array}{l}\text { Lafuente Martinez et } \\
\text { al. }{ }^{[19]}\end{array}$ & $17, M$ & Knee & Intraarticular injection & Amikacin & Recovery \\
\hline Watanakunakorn ${ }^{[25]}$ & $69, F$ & Sternoclavicular & Subclavian catheter & $\begin{array}{l}\text { Ceftizoxime }+ \\
\text { gentamicin }\end{array}$ & Recovery \\
\hline Svensson et al. ${ }^{[26]}$ & $\begin{array}{l}2 \text { cases } 46, M \\
40, M\end{array}$ & Hip, ankle & $\begin{array}{l}\text { Diabetes + UTI } \\
\text { postoperative infection }\end{array}$ & $\begin{array}{l}\text { TMP-SMX + } \\
\text { cefotaxime } \\
\text { ceftazidime }\end{array}$ & $\begin{array}{l}\text { Difficulty walking } \\
\text { Recovery }\end{array}$ \\
\hline Nakashima et al. ${ }^{[17]}$ & 8 cases & Knee, shoulder & $\begin{array}{l}\text { Epidemic due to contaminated } \\
\text { benzalkonium chloride }\end{array}$ & Unspecified & Unspecified \\
\hline Greene $^{[27]}$ & $16, M$ & Ankle & Foreign body remnants (splinter) & Cefotaxime & Recovery \\
\hline Carmichael $^{[28]}$ & 15 months, $M$ & Vertebra & Broviac catheterization & Ceftriaxone & Difficulty walking \\
\hline Chiu and Wang ${ }^{[21]}$ & $34, M$ & Knee & $\begin{array}{l}\text { Traffic accident, contaminated } \\
\text { wound }\end{array}$ & TMP-SMX & Joint restriction \\
\hline Hadid et al. ${ }^{[20]}$ & $72, \mathrm{M}$ & Ankle & $\begin{array}{l}\text { Minor trauma contaminated with } \\
\text { soil }\end{array}$ & Ertapenem & Recovery \\
\hline Sandal et al. ${ }^{[22]}$ & 10 weeks, $\mathrm{M}$ & Knee & Escobar syndrome & Meropenem & Recovery \\
\hline
\end{tabular}

UTI: Urinary tract infection TMP-SMX: Trimethoprim-sulfamethoxazole, M: Male, F: Female

of nosocomial septic arthritis, we believe that this was a case of community-based septic arthritis resulting from contamination of an open/dirty wound, because the procedure was performed in sterile operating room conditions and we have never encountered such complications after this frequently performed procedure $^{[32]}$.

Since our patient presented with a dirty wound, treatment was started with cefazoline + gentamicin as is routine in our orthopedic clinic. When arthritis appeared after three days and Gram-negative bacilli were observed in the SF, treatment was changed to piperacillin-tazobactam in accordance with treatment guidelines. There was still no response to treatment after one week, leading us to suspect low generic antibiotic activity, so ertapenem treatment was started and continued for four weeks. Gram-positive agents, especially S. aureus, are the first to come to mind in community-acquired septic arthritis, and empirical treatment usually targets these microorganisms. Therefore, it is observed in the literature that there is a delay of 3-21 days (mean 12 days) in the diagnosis of septic arthritis, mostly due to Gram-negative bacteria ${ }^{[8,33]}$. It should be kept in mind that delayed or inappropriate treatment lead to more serious complications in septic arthritis, especially with more aggressive Gram-negative agents, and that Gram-negative bacteria such as $S$. marcescens may be the etiologic factor in posttraumatic arthritis, even in the absence of an underlying immunosuppressive condition.

\section{Ethics}

Informed Consent: Consent form was filled out by the reported case.

Peer-review: Externally and internally peer-reviewed.

\section{Authorship Contributions}

Surgical and Medical Practices: A.I.O., A.A., S.T., Analysis or Interpretation: A.I.O., B.Ş., H.E., Literature Search: A.I.O., B.Ş., T.A, Writing: A.I.O.

Conflict of Interest: No conflict of interest was declared by the authors.

Financial Disclosure: The authors declared that this study received no financial support. 


\section{References}

1. Goldenberg DL, Reed JI. Bacterial arthritis. N Engl J Med. 1985;312:764-71.

2. Mathews CJ, Coakley G. Septic arthritis: current diagnostic and therapeutic algorithm. Curr Opin Rheumatol. 2008;20:457-62.

3. Olut Al, Avcı M, Ozgenç O, Altay T, Coşkuner SA, Ozsu Caymaz S, Havuk A. Septic arthritis of hip due to Salmonella typhi in a patient with multiple sclerosis. Mikrobiyol Bul. 2012;46:113-6.

4. Kaandorp CJ, Dinant HJ, van de Laar MA, Moens HJ, Prins AP, Dijkmans BA. Incidence and sources of native and prosthetic joint infection: a community based prospective survey. Ann Rheum Dis. 1997;56:470-5.

5. Öztuna V. Septic arthritis. TOTBID Dergisi. 2010;9:101-6.

6. Goodman SB, Chou LB, Schurman DJ. Management of pyarthrosis. In: Chapman MW, (ed). Chapman's orthopaedicsurgery. 3rd ed. Philadelphia: Lippincott Williams \& Wilkins, 2001:3561-77.

7. Pollard H, Granger $\mathrm{S}$, Tuchin PJ. Bacterial arthritis. A review. Australas Chiropr Osteopathy. 1999;8:45-53.

8. Goldenberg DL, Brandt KD, Cathcart ES, Cohen AS. Acute arthritis caused by Gram-negative bacilli: a clinical characterization. Medicine (Baltimore) 1974;53:197-208.

9. Bayer AS, Chow AW, Louie JS, Nies KM, Guze LB. Gram-negative bacillary septic arthritis: clinical, radiographic, therapeutic, and prognostic features. Semin Arthritis Rheum. 1977;7:123-32.

10. Patti JM, Bremell T, Krajewska-Pietrasik D, Abdelnour A, Tarkowski A, Rydén C, Höök M. The Staphylococcus aureus collagen adhesin is a virulence determinant in experimental septic arthritis. Infect Immun. 1994;62:152-61.

11. Bayer AS, Chow AW, Louie JS, Nies KM, Guze LB. Gram-negative bacillary septic arthritis: clinical, radiographic, therapeutic, and prognostic features. Semin Arthritis Rheum. 1977;7:123-32.

12. CLSI. Performance Standards for Antimicrobial Susceptibility Testing; Twenty-Third Informational Supplement. CLSI document M100-S23. Wayne, PA: Clinical and Laboratory Standards Institute, 2013.

13. Atlas $E_{1}$ Belding ME. Serratia marcescens arthritis requiring amputation JAMA. 1968;8:167-9.

14. Lin WT, Tang HJ, Lai CC, Chao CM. Clinical manifestations and bacteriological features of culture-proven Gram-negative bacterial arthritis. J Microbio Immunol Infect. 2017;50:527-31.

15. Wilhelmi I, Bernaldo de Quirós CJ, Romero-Vivas J, Duarte J, Rojo E, Bouza E. Epidemic outbreak of Serratia marcescens infection in a cardiac surgery unit. J Clini Microbiol. 1987;25:1298-300.

16. Donovan TL, Chapman MW, Harrington KD, Nagel DA Serratia arthritis Report of seven cases. J Bone Joint Surg Am. 1976;58:1009-11.

17. Nakashima AK, McCarthy MA, Martone WJ, Anderson RL. Epidemic septic arthritis caused by Serratia marcescens and associated with a benzalkonium chloride antiseptic. J Clin Microbiol. 1987;25:1014-8.
18. Ross GN, Baraff $\amalg$, Quismorio FP. Serratia arthritis in heroin users. J Bone Joint Surg Am. 1975;57:1158-60.

19. Lafuente Martinez D, Bonilla Velasco FA, Sampedro Alvarez J, Menendez Lozano A. Septic arthritis caused by Serratia marcescens. Arthritis Rheum. 1981;24:567-8.

20. Hadid H, Usman M, Thapa S. Severe Osteomyelitis and Septic Arthritis due to Serratia marcescens in an Immunocompetent Patient. Case Rep Infect Dis. 2015;2015:347652.

21. Chiu LQ, Wang WA. Case of unusual Gram-negative bacilli septic arthritis in an immunocompetent patient. Singapore Med J. 2013;54:164-8.

22. Sandal ÖS, Sarı F, Ceylan G, İşgüder R, Devrim I, Ağın H. Serratia marcescens Septic Arthritis in a Case of Escobar Syndrome. J Pediatr Emerg Intensive Care Med. 2017;4:84-8.

23. Burton DS, Nagel DA. Serratia marcescens infections in orthopaedic surgery. A review of the literature and a report of two cases. Clin Orthop Relat Res. 1972;89:145-9.

24. Rogala EJ, Cruess RL. Multiple pyogenic arthritis due to Serratia marcescens following renal homotransplantation. Report of a case. J Bone Joint Surg Am. 1972;54:1283-7.

25. Watanakunakorn C. Serratia marcescens osteomyelitis of the clavicle and sternoclavicular arthritis complicating infected indwelling subclavian vein catheter. Am J Med. 1986;80:753-4.

26. Svensson 0, Parment PA, Blomgren G. Orthopaedic infections by Serratia marcescens: a report of seven cases. Scand J Infect Dis. 1987;19:69-75.

27. Greene WB. Unrecognized foreign body as a focus for delayed Serratia marcescens osteomyelitis and septic arthritis. Two case reports. J Bone Joint Surg Am. 1989;71:754-7.

28. Carmichael KD. Childhood septic arthritis following treatment of spondylodiskitis from Serratia marcescens. Orthopedics. 2003;26:519-21.

29. Stock I, Burak S, Sherwood KJ, Grueger T, Wiedemann B. Natural antimicrobial susceptibilities of 'unusual' Serratia species: S. ficaria S. fonticola, S. odorifera, S. plymuthica and S. rubidaea. J Antimicrob Chemother. 2003;51:865-85.

30. Ohl AC. Infectious arthritis of native joints. In: Mandell GL, Bennett JE, Dolin $R$ (edS). Principals and Practice of Infectious Diseases. $7^{\text {th }}$ ed. Philadelphia: Churchill Livingstone, 2010:1443-56.

31. Stock I, Grueger T, Wiedemann B. Natural antibiotic susceptibility of strains of Serratia marcescens and the S. liquefaciens complex: S. liquefaciens sensu stricto, S. proteamaculans, and S. grimesii. Int J Antimicrob Agents. 2003;22:35-47.

32. Garner JS, Jarvis WR, Emori TG, Horan TC, Hughes JM. CDC definitions for nosocomial infections, 1988. Am J Infect Control 1988;16:128-40.

33. Feldman LS. Salmonella septic sacroiliitis; case report and review. Pediatr Infect Dis J 2006;25:187-9. 